(2)

\section{OPEN ACCESS}

\title{
COVID-19 myocarditis and postinfection Bell's palsy
}

\author{
Elin Hoffmann Dahl ำ, ${ }^{1}$ Knut Anders Mosevoll, ${ }^{1}$ Dana Cramariuc, ${ }^{2}$ \\ Christian Alexander Vedeler, ${ }^{3}$ Bjørn Blomberg (1) ${ }^{4,5}$
}

\begin{abstract}
'Department of Medicine, Haukeland Universitetssjukehus, Bergen, Norway

${ }^{2}$ Department of Cardiology, Haukeland Universitetssjukehus, Bergen, Norway ${ }^{3}$ Department of Neurology, Haukeland Universitetssjukehus, Bergen, Norway ${ }^{4}$ Department of Clinical Science, Universitetet i Bergen, Bergen, Hordaland, Norway ${ }^{5}$ National Advisory Unit for Tropical Infectious Diseases, Department of Medicine, Haukeland Universitetssjukehus, Bergen, Norway
\end{abstract}

Correspondence to Dr Bjørn Blomberg: bjorn.blomberg@uib.no

Accepted 5 December 2020

Check for updates

(c) BMJ Publishing Group Limited 2021. Re-use permitted under CC BY-NC. No commercial re-use. See rights and permissions. Published by BMJ.

\begin{tabular}{l}
\hline To cite: Dahl EH, \\
Mosevoll KA, Cramariuc D, \\
et al. BMJ Case Rep \\
2021;14:e240095. \\
doi:10.1136/bcr-2020- \\
240095
\end{tabular}

\section{SUMMARY}

Here we present the case of a 37-year-old previously healthy man who developed fever, headache and a unilateral, painful neck swelling while working offshore. He had no known contact with anyone with COVID-19; however, due to the ongoing pandemic, a nasopharyngeal swab was performed, which was positive for the virus. After transfer to hospital for assessment his condition rapidly deteriorated, requiring admission to intensive care for COVID-19 myocarditis. One week after discharge he re-presented with unilateral facial nerve palsy. Our case highlights an atypical presentation of COVID-19 and the multifaceted clinical course of this still poorly understood disease.

\section{BACKGROUND}

In the early stages of the SARS-CoV-2 pandemic, COVID-19 was characterised primarily as a respiratory disease with complications including acute respiratory distress syndrome. It is now clear that COVID-19 can affect multiple organ systems with a wide range of short-term, medium-term and longterm complications. ${ }^{12}$ COVID-19 myocarditis is an important though still poorly understood phenomenon. ${ }^{3}$ Case reports have documented that younger, previously healthy patients can develop significant cardiac injury even with milder disease presentations. ${ }^{4}$ Prompt detection, isolation and management of the virus in order to minimise transmission and reduce complications rely on recognising the spectrum of clinical presentations, including cardiac and neurological manifestations.

\section{CASE PRESENTATION}

A previously healthy 37-year-old man developed fever, headache and a unilateral, painful neck swelling while working on an offshore platform. He had no significant medical history, no recent international travel and no known contact with anyone with COVID-19. Despite his presenting symptoms giving little indication of COVID-19 infection, for training purposes in the early phase of the pandemic he was transported in an EpiShuttle (single-patient isolation transport system) when he was evacuated to hospital for assessment.

On admission he had an area of redness in the posterior palate and a tender, non-fluctuant swelling extending from the left mandibular angle towards the sternocleidomastoid muscle. He denied any cough, neck stiffness, pain on swallowing, respiratory distress or chest pain.

$\mathrm{He}$ was febrile at $41^{\circ} \mathrm{C}$, tachycardic at 115 beats per minute, normotensive at $119 / 76 \mathrm{~mm}$ $\mathrm{Hg}$ and mentally alert. He had an intermittently raised respiratory rate varying between 12 and 22 breaths per minute and a peripheral oxygen saturation of $100 \%$ on room air. Systemic examination, including auscultation of the heart and lungs, was unremarkable.

A routine ECG showed sinus tachycardia with moderately flattened T-waves (figure 1 ). His chest $\mathrm{X}$-ray was unremarkable.

Due to the combination of fever and mild respiratory distress, we performed an arterial blood gas. This showed a picture of respiratory alkalosis (on room air: $\mathrm{pH} 7.55$; partial pressure of carbon dioxide $3.9 \mathrm{kPa}$; partial pressure of oxygen $8.4 \mathrm{kPa}$; bicarbonate $23 \mathrm{mmol} / \mathrm{L}$ ).

Routine admission blood tests showed an elevated $\mathrm{C}$ reactive protein $(\mathrm{CRP})$ of $230 \mathrm{mg} / \mathrm{L}(0-5 \mathrm{mg} / \mathrm{L})$ and procalcitonin of $2.1 \mu \mathrm{g} / \mathrm{L}(0-0.10 \mu \mathrm{g} / \mathrm{L})$, with normal leucocytes at $7.1 \times 10^{9} / \mathrm{L}\left(3.5-11.0 \times 10^{9} / \mathrm{L}\right)$. The panel also revealed elevated troponin $\mathrm{T}(\mathrm{TnT})$ at $90 \mathrm{ng} / \mathrm{L}(0-15 \mathrm{ng} / \mathrm{L})$. Blood was then further evaluated for $\mathrm{N}$-terminal pro-B-type natriuretic peptide (NT-proBNP), which was also raised at $160 \mathrm{ng} / \mathrm{L}$ $(0-85 \mathrm{ng} / \mathrm{L})$. Echocardiography showed good ventricular function without hypokinesia and no significant valve pathology.

A CT of the neck was performed to assess the neck swelling. This showed subcutaneous oedema on the left side with multiple enlarged lymph nodes up to $2.0 \times 2.7 \mathrm{~cm}$ in diameter.

Echocardiography was repeated on day 2 revealing a deterioration of the left ventricular function with reduced systolic function of $40 \%$ (video 1). The infectious parameters CRP rose to $344 \mathrm{mg} / \mathrm{L}$ and procalcitonin to $12.9 \mu \mathrm{g} / \mathrm{L}$, while the leucocytes remained normal.

On day 3 after admission he was transferred to intensive care due to respiratory distress.

\section{DIFFERENTIAL DIAGNOSIS}

Initially, on admission cellulitis on the neck was suspected and the patient was started on broadspectrum antibiotics cefotaxime and clindamycin to cover for bacterial pathogens, including oral flora. He did not fulfil the criteria for sepsis.

Based on blood markers (raised TnT, raised NT-proBNP) and echocardiography, cardiac involvement was suspected. In the absence of chest pain myocardial infarction was thought to be less likely, but myocarditis was suggested as differential diagnosis. He received acetylsalicylic acid $300 \mathrm{mg}$ and was observed with telemetry, and a CT angiogram and cardiac MRI was planned to clarify the diagnosis.

Despite a low clinical suspicion of COVID-19 with lack of contact and an atypical clinical 


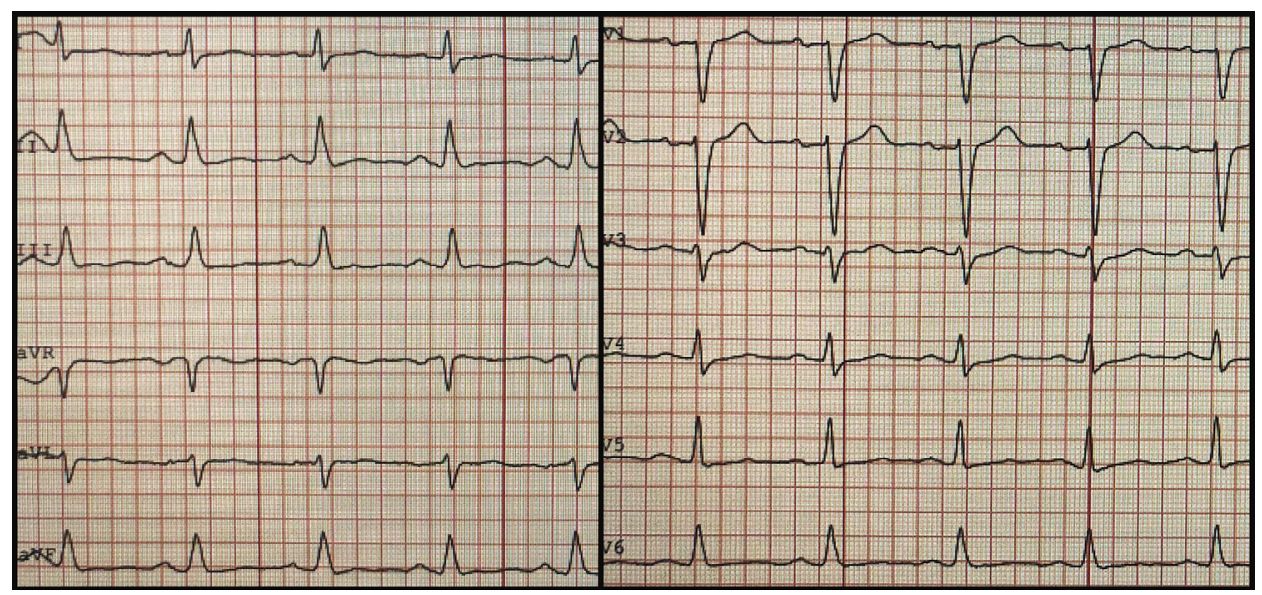

Figure 1 ECG on admission showing sinus tachycardia with moderately flattened T-waves.

presentation, a nasopharyngeal swab was performed due to the ongoing pandemic, which was positive on reverse transcription PCR for SARS-CoV-2.

\section{TREATMENT}

On day 3 after admission the patient's condition deteriorated. He developed respiratory distress, saturating $94 \%$ on room air and was placed on $3 \mathrm{~L} / \mathrm{min}$ of oxygen. Repeat arterial blood gas showed lactate of $3.2 \mathrm{mmol} / \mathrm{L}$ and partial pressure of arterial oxygen $\left(\mathrm{PaO}_{2}\right)$ of 6.3 .

He also had oliguria and hypotension $(83 / 41 \mathrm{~mm} \mathrm{Hg})$ despite sufficient administration of fluids and therefore invasive haemodynamic monitoring was instituted. Transpulmonary thermodilution measurements using pulse-induced contour cardiac output (PiCCO) monitoring indicated a high-preload, hyperdynamic, vasodilated state. He received intravenous furosemide and intermittently required low-dose norepinephrine infusion to maintain a middle arterial pressure of $>60 \mathrm{~mm} \mathrm{Hg}$, which normalised his urine output.

Continuous positive airway pressure was given intermittently, alternating with oxygen $(2 \mathrm{~L} / \mathrm{min})$ by nasal cannula, on which oxygen saturation remained $>93 \%$. A repeat X-ray showed bibasal consolidations (figure 2). TnT and NT-proBNP rose

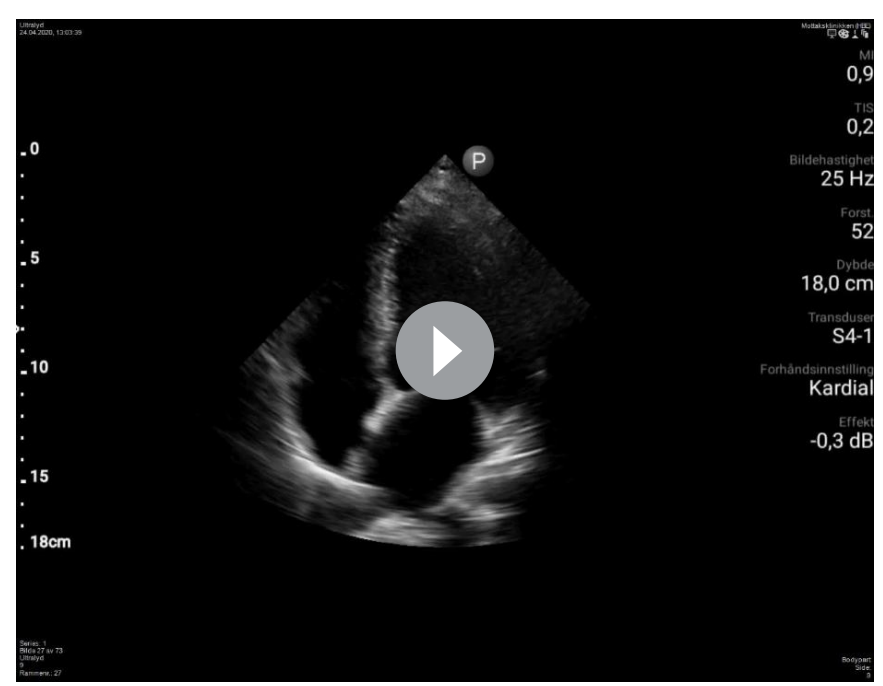

Video 1 Echocardiography on day 2 of admission showing reduced systolic function of $40 \%$. to a maximum of $1959 \mathrm{ng} / \mathrm{mL}$ and $11169 \mathrm{ng} / \mathrm{L}$, respectively (figure 3).

On day 5 after admission a cardiac MRI was performed revealing diffuse myocardial oedema (video 2) suggestive of significant acute myocardial injury. The CT angiogram showed no coronary artery stenosis.

His condition gradually improved and he was discharged 11 days after admission.

\section{OUTCOME AND FOLLOW-UP}

One week after discharge the patient was readmitted with unilateral, right-sided peripheral facial nerve palsy. Neurological examination and his general clinical status were otherwise unremarkable. We performed a cerebral CT scan which was normal. Spinal fluid examination revealed elevated protein of $1.0 \mathrm{~g} / \mathrm{L}$ $(0.2-0.4 \mathrm{~g} / \mathrm{L}), \operatorname{IgG}$ of $0.14 \mathrm{~g} / \mathrm{L}(0.02-0.040 \mathrm{~g} / \mathrm{L})$ and mild mononuclear pleocytosis at $7 \times 10^{6} / \mathrm{L}\left(0-5 \times 10^{6} / \mathrm{L}\right)$.

$\mathrm{He}$ was empirically treated with doxycycline for suspected borreliosis, which is endemic in the region, and was discharged. However, subsequent analysis of blood and spinal fluid did not detect any anti-Borrelia antibodies. He had borderline raised C-X-C motif chemokine 13 (CXCL13) of $20.3 \mathrm{pg} / \mathrm{mL}(<20.0)$

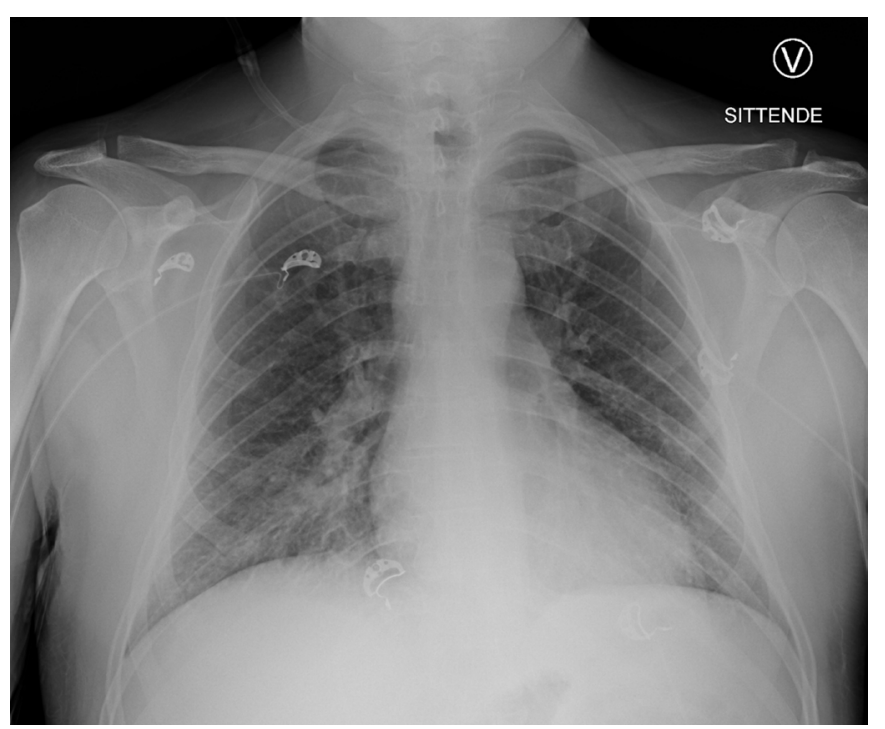

Figure 2 Chest $\mathrm{X}$-ray on day 2 showing diffuse infiltrates in both lower lung fields. 


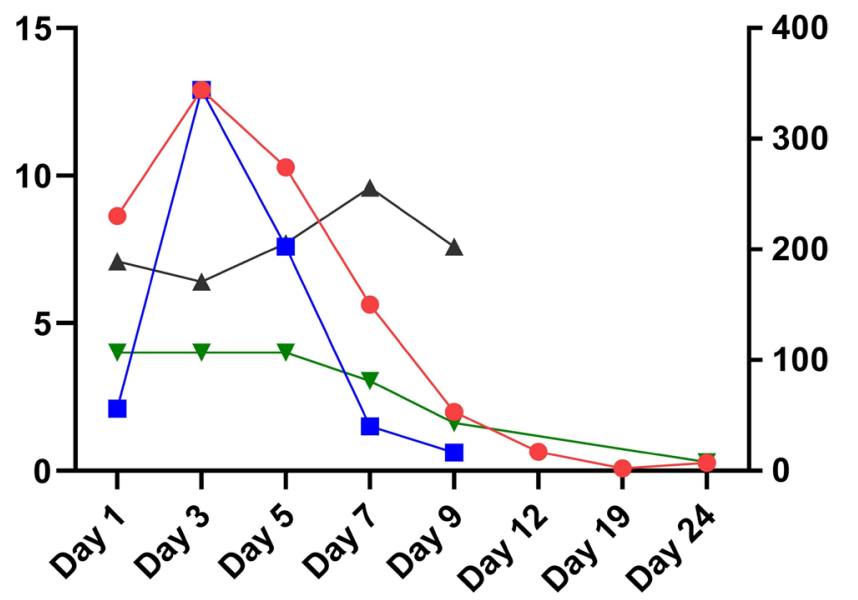

- $\mathrm{CRP} \mathrm{m} / \mathrm{L}$, right axis

- PCT $\mu g / L$, left axis

$\rightarrow$ WBC $10^{*}$ 9/L, left axis

$\rightarrow$ D-dimer mg/L FEU, left axis
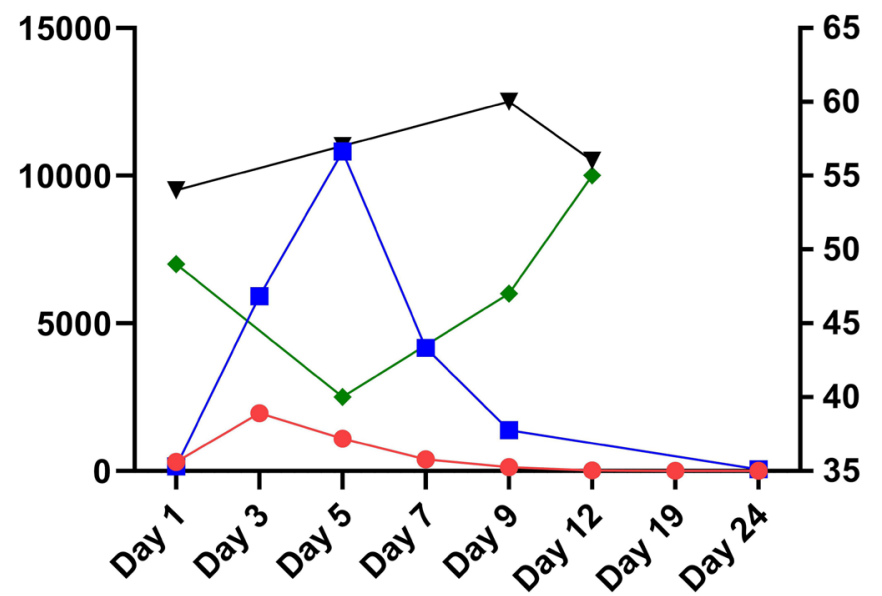

- TroponinT ng/L left axis

-n NT-proBNP ng/L left axis

$\rightarrow \operatorname{LVEDD}(\mathrm{mm})$ right axis

$\rightarrow$ EF $(\%)$ right axis

Figure 3 Timeline of echocardiography measurements and blood values. CRP, C reactive protein; NT-proBNP, N-terminal pro-B-type natriuretic peptide. FEU, fibrinogen equivalent units, $\mathrm{PCT}$, procalcitonin, WBC, white blood cells, LVEDD, left ventricular end-diastolic diameter, $E F$, ejection fraction.

in the cerebrospinal fluid, which does not differentiate between neuroborreliosis and other inflammatory processes. PCR on spinal fluid was negative for neurotropic agents, including SARS-CoV-2.

Using a recently validated assay ${ }^{6}$ we found high levels of antiSARS-CoV-2 IgG antibodies in the serum $(19.1 \mu \mathrm{g} / \mathrm{mL})$ and low levels in the spinal fluid $(0.3 \mu \mathrm{g} / \mathrm{mL})$. Antibody index, that is, spinal to serum ratio of specific $\operatorname{IgG}(0.3 \mu \mathrm{g} / \mathrm{mL}: 19.1 \mu \mathrm{g} / \mathrm{mL})$ divided by the spinal to serum ratio of the total $\operatorname{IgG}(0.14 \mathrm{~g} / \mathrm{L}: 13.3 \mathrm{~g} / \mathrm{L})$, was 1.47 , indicating no definite intrathecal specific antibody production

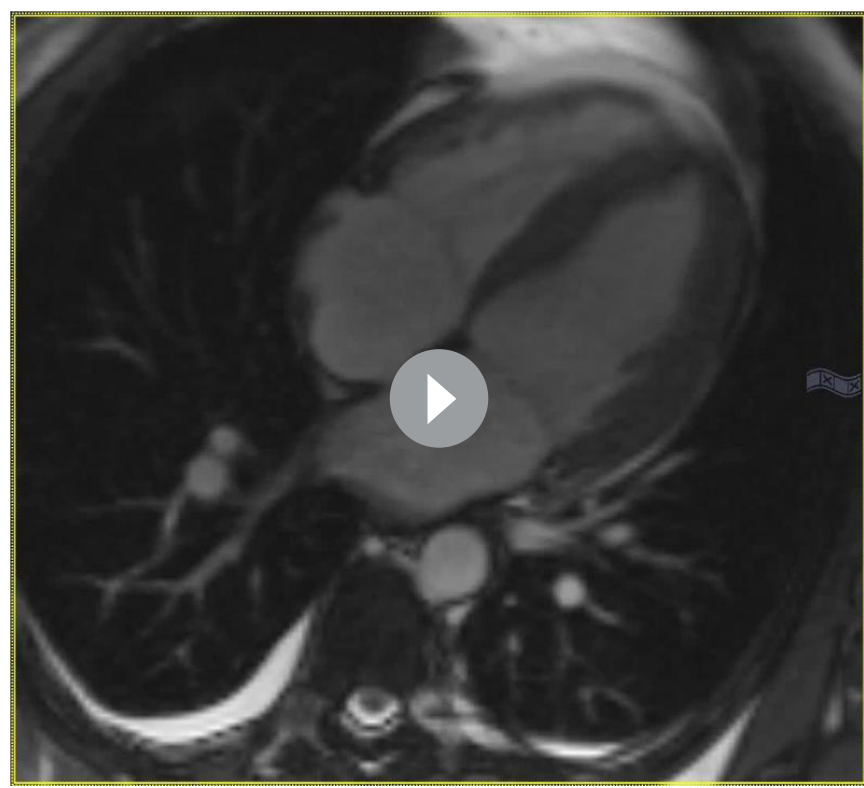

Video 2 Cardiac MRI on day 5 showing diffuse myocardial oedema and mild pericardial effusion.

(cut-off $<2.0$ ). Antiganglioside antibodies (anti-GD1b IgG and antiGM1 IgG) were detected in the serum obtained on readmission for facial palsy, but were not detectable in the serum obtained during his initial admission 2 weeks prior. Cerebral MRI performed after discharge was normal.

The patient subsequently recovered completely from his facial palsy. However, several months after admission he is still experiencing decreased exercise tolerance.

\section{DISCUSSION}

Our case report describes a complex, multifaceted manifestation of COVID-19 in a previously healthy young man.

He initially presented with fever and neck swelling and received broad-spectrum antibiotics to cover for possible bacterial neck infection. However, blood and throat swab culture did not yield pathogens, and taken together with clinical and radiological

\section{Patient's perspective}

I'm doing better, but I still feel reduced. Because I feel stiffness and tiredness in the body I'm still not able to go back to work. My hands are numb and with a sensation of tingling, especially in cold water. Otherwise I'm in good spirits.

\section{Learning points}

Unusual presentations of COVID-19 present a risk of being overlooked, leading to delayed diagnosis, isolation and effective management of people with the infection.

- Cardiac complications of COVID-19 infection can occur in otherwise healthy young people, and whether susceptibility reflects inflammatory response, autoimmune factors or another mechanism altogether remains unclear.

- Bell's palsy secondary to COVID-19 infection can occur and is likely to be of autoimmune pathogenesis. 
findings we feel this is more consistent with SARS-CoV-2 reactive adenitis.

The myocardial dysfunction occurred during the initial febrile period, and although we did not perform a myocardial biopsy his otherwise comprehensive evaluation suggests he had viral myocarditis caused by COVID- 19 .

Acute myocardial dysfunction during the early course of COVID-19 has been retrospectively reported in $16 \%{ }^{7}-36 \%{ }^{8}$ of patients and is associated with significantly higher mortality. Aetiology remains unclear, but cardiac damage in COVID-19 has been suggested to be attributed to stress-induced cardiomyopathy and immunological and microvascular damage. ${ }^{3}$ Case reports have documented that younger, previously healthy patients can develop significant regional cardiac injury due to acute coronary thrombosis in COVID-19, even with milder disease presentations. ${ }^{45}$ In our patient, the myocardial involvement was global, suggesting diffuse inflammatory damage as a more probable pathway than regional ischaemic dysfunction due to microvascular thrombosis or atherosclerotic plaque rupture. ${ }^{9}$ A particularity of the present case is the significant amount of myocardial injury, as reflected by an increase in $\operatorname{TnT}$ to $>3 \times$ upper limit of normal combined with ECG and echocardiographic abnormalities, despite the patient's young age and the absence of previous cardiovascular disease. The mechanisms underlying and the predisposition to COVID-19 myocarditis in young, otherwise healthy individuals remain poorly understood and are a research priority. ${ }^{3}$

Both central neurological manifestations, such as encephalopathy, seizures and ataxia, and peripheral nerve damage have been attributed to COVID-19, including frequent reports of loss of taste and smell, and rarely cranial neuritis mainly affecting eye movement. ${ }^{10-13}$ Whether SARS-CoV-2 actually displays neurotropism is currently not clear. ${ }^{10}$ In our patient, the low antibody index indicates there has not been viral replication within the central nervous system. The development of ganglioside antibodies during the course of the infection and the manifestation of Bell's palsy only after he had recovered from the initial febrile infection support that the palsy has autoimmune pathogenesis.

Acknowledgements We thank the Bergen COVID-19 Research Group for their valuable input in the conceptualisation and writing of this case report: Rebecca Jane Cox, Karl Albert Brokstad, Florian Krammer, Nina Langeland, Helene Skjefte, Kristin Greve Isdahl Mohn, Camilla Tøndel, Fabian Åhrberg, Nicolai Maroni Johannessen, Lebaneng Abel, Jonas Torp Ohlsen and Siri Marie Blomberg.
Contributors All five authors fulfil the authorship criteria. EHD, KAM and BB contributed to the conception of the case report, acquisition and interpretation of data, drafting of the article, as well as critically revising it for important intellectual content. CAV and DC contributed to the analysis and interpretation of data and critically revising it for important intellectual content.

Funding The authors have not declared a specific grant for this research from any funding agency in the public, commercial or not-for-profit sectors.

Competing interests None declared.

Patient consent for publication Obtained.

Provenance and peer review Not commissioned; externally peer reviewed.

Open access This is an open access article distributed in accordance with the Creative Commons Attribution Non Commercial (CC BY-NC 4.0) license, which permits others to distribute, remix, adapt, build upon this work non-commercially, and license their derivative works on different terms, provided the original work is properly cited and the use is non-commercial. See: http://creativecommons.org/ licenses/by-nc/4.0/.

\section{ORCID iDs}

Elin Hoffmann Dahl http://orcid.org/0000-0002-0102-7462

Bjørn Blomberg http://orcid.org/0000-0001-5647-4297

\section{REFERENCES}

1 del Rio C, Collins LF, Malani P. Long-Term health consequences of COVID-19. JAMA 2020;324:1723-4.

2 Gupta A, Madhavan MV, Sehgal K, et al. Extrapulmonary manifestations of COVID-19. Nat Med 2020;26:1017-32.

3 Topol EJ. COVID-19 can affect the heart. Science 2020;370:408-9.

4 Ranard LS, Engel DJ, Kirtane AJ, et al. Coronary and cerebral thrombosis in a young patient after mild COVID-19 illness: a case report. Eur Heart J Case Rep 2020;4:1-5

5 Ho JS, Sia C-H, Chan MY, et al. Coronavirus-Induced myocarditis: a meta-summary of cases. Heart Lung 2020;49:681-5.

6 Amanat F, Stadlbauer D, Strohmeier S, et al. A serological assay to detect SARS-CoV-2 seroconversion in humans. Nat Med 2020;26:1033-6.

7 Lala A, Johnson KW, Januzzi JL, et al. Prevalence and impact of myocardial injury in patients hospitalized with COVID-19 infection. J Am Coll Cardiol 2020;76:533-46.

8 Wei J-F, Huang F-Y, Xiong T-Y, et al. Acute myocardial injury is common in patients with COVID-19 and impairs their prognosis. Heart 2020;106:1154-9.

9 Giustino G, Croft LB, Stefanini GG, et al. Characterization of myocardial injury in patients with COVID-19. J Am Coll Cardiol 2020;76:2043-55. doi:10.1016/j. jacc.2020.08.069

10 Mao L, Jin H, Wang M, et al. Neurologic manifestations of hospitalized patients with coronavirus disease 2019 in Wuhan, China. JAMA Neurol 2020;77:683.

11 Helms J, Kremer S, Merdji H, et al. Neurologic features in severe SARS-CoV-2 infection. N Engl J Med 2020;382:2268-70.

12 Wu Y, Xu X, Chen Z, et al. Nervous system involvement after infection with COVID-19 and other coronaviruses. Brain Behav Immun 2020;87:18-22.

13 Gutiérrez-Ortiz C, Méndez-Guerrero A, Rodrigo-Rey S, et al. Miller Fisher syndrome and polyneuritis cranialis in COVID-19. Neurology 2020;95:e601-5.

Copyright 2021 BMJ Publishing Group. All rights reserved. For permission to reuse any of this content visit

https://www.bmj.com/company/products-services/rights-and-licensing/permissions/

BMJ Case Report Fellows may re-use this article for personal use and teaching without any further permission.

Become a Fellow of BMJ Case Reports today and you can:

- Submit as many cases as you like

- Enjoy fast sympathetic peer review and rapid publication of accepted articles

- Access all the published articles

Re-use any of the published material for personal use and teaching without further permission

Customer Service

If you have any further queries about your subscription, please contact our customer services team on +44 (0) 2071111105 or via email at support@bmj.com.

Visit casereports.bmj.com for more articles like this and to become a Fellow 